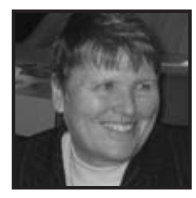

\title{
Commentary:
}

\section{Narrative Conceptualizations of Student Engagement ${ }^{1}$}

\author{
Jean Clandinin, University of Alberta
}

\section{ABSTRACT}

This commentary explores what it might mean to conceptualize student engagement narratively, that is, by conceptualizing it in terms of the curricula that children and teachers are living out in classrooms. It draws on recent school-based narrative inquiries and earlier theoretical work on curriculum making as negotiating a curriculum of lives. Thinking narratively about student engagement puts lives at the centre of curriculum making and calls forward questions about educators' purposes and intentions in schools.

$\mathrm{n}$ the classroom I watch as the teacher asks the children in this urban multicultural classroom to connect their lives to a book she is reading aloud to them. The book is part of an ongoing study of citizenship threaded around questions of student identity and belonging. The picture book (Say, 1999) is about a young woman of Japanese heritage who grows up in the United States and, as a teenager, is taken back to Japan by her parents. She struggles with the unfamiliar cultural, institutional and social landscapes in which she finds herself. As the teacher reads, I see the children looking at the pictures intently, caught up by the story. The children are quiet, focused. As she finishes reading, the teacher asks them to think about moments when they felt uncertain about who they were and what was happening for them. Many children raise their hands and, one by one, they begin to tell their stories. One child of Korean heritage, whose head has been down for some time, slowly raises his hand and begins to tell of being in an unfamiliar landscape 
when he moved to a new school. The children called him "Little Chinese Boy." As he shares this story filled with tension in the living and perhaps in the telling, some children and the teacher nod in quiet unison, seemingly sharing a common understanding. Other children begin to tell other tension-filled stories. The children listen intently to each other, as each story telling seems to evoke other stories, stories of moments of uncertainty where they longed to belong. The teacher, finding her childhood stories resonating with those being told by the children, shares her own story of uncertainty as response.

My mind slips back several months to another moment when another teacher was in the same classroom and the students were also learning about the social, cultural and institutional landscapes of another country. The teacher was having the students take turns reading from a textbook filled with colorful illustrations of the country they were studying. In this moment, the teacher has called on a student whose family comes from this particular country. She was called to stand beside the teacher and to speak about the country, identifying language, religion and customs such as celebrations. The child, now positioned as expert in relation to her classmates, responded to the teacher's questions, sometimes with short answers, sometimes with puzzled looks and corrections to what the teacher said. I watched the other children shuffle in their desks, talk to others close by. I watched as one child built a structure out of his name card, pencils and pencil box. Other children watched him, as I did, and, wordlessly, others began to devise similar structures on their desks. The child sat down and the class returned to reading the textbook, each child taking a turn.

These story fragments call me to wonder about student engagement. At one level it is easy to say that in the first fragment the children are engaged in the task the teacher set before them; in the second they are not engaged in the teacher-set task. However, in the second fragment, there was the possibility of student engagement, both in the shared moment between the child positioned as expert and the teacher and as the children carefully watched each other and, in a wordless agreement, composed a shared story of building structures, an undertaking not unrelated to the ongoing science unit around building and conducting fair tests of strength. In each fragment, I wonder how the teacher would have thought about student engagement. For example, in the second, I wonder if the teacher noticed the shared engagement swirling around her and the child-expert beside her. Would she have named the students' shared engagement as engagement or would she have only named her work with the child as the focal point for engagement as their negotiation was more in line with the curricular outcomes of that particular mandated curriculum? 
What do we mean by student engagement and can we think of it in narrative terms? A dictionary check offers words such as "the act of sharing in the activities of a group", "involvement", "participation", "commitment", and "intervention". These words are contrasted with "non-engagement, non-involvement, and nonparticipation-withdrawing from the activities of a group". These words do not easily help me see one of the situations above as engagement and the other as non-engagement for in both the children were engaged, in one instance, resonating in unique and varied ways with the teacher helping them think about questions of belonging and in the second with sharing a moment of constructing as the planned curriculum was enacted around them as a kind of main text to students' lived texts. If we think of student engagement as only what the teacher intended for engagement in that moment, we could more easily make a distinction. But is that a distinction that allows us to think about what children are experiencing? Does it move us to a more thoughtful understanding of student engagement that might help deepen both our understandings of what it means to speak of engagement and how it connects to curriculum making in classrooms? Can we somehow connect notions of student engagement with more narrative notions of experience as curriculum is made in classrooms?

Does reimagining student engagement in more narrative terms as curriculum is lived in classrooms help us move to new understandings of what is happening in classrooms? Does it help us understand what is important about student engagement, in terms of children's and teachers' experiences in curriculum making?

\section{Understanding Curriculum Making as a Negotiated Narrative Composition}

In our work we see each curriculum situation as the interaction of four curriculum commonplaces-learner, teacher, subject matter, and milieu (Connelly \& Clandinin, 1988). At one level this seems simple enough but, as we begin to work in classrooms in the moments of lived curriculum making, we see the ongoing negotiation of curriculum. As a consequence, we attend to each commonplace in relation to the others, in shifting relational ways. While we recognize there are different ways of thinking about curriculum, that is, as mandated, planned and lived curriculum, we, most often, attend to the lived curriculum, which is shaped by the planned and mandated curriculum. Attending to the curriculum being negotiated among lives in relation in schools, we think about a curriculum of lives (Aoki, 1993; Clandinin \& Connelly, 1992; Portelli \& Vibert, 2001). 
Attending to the interaction of the curriculum commonplaces, we attend to each commonplace in narrative ways. To understand teachers, we need to understand each teacher's personal practical knowledge, his/her embodied, narrative, moral, emotional, and relational knowledge as it is expressed in practice (Clandinin \& Connelly, 1995). To understand children, we need to understand children's knowledge as nested knowledge, nested in the relational knowing between teachers and children (Lyons, 1990; Murphy, 2004). We need to attend to different kinds of storiessecret, sacred, and cover stories-as we attend to stories of teachers and teachers' stories (Clandinin \& Connelly, 1996). Like their teachers, children also hold and express their knowledge in secret and cover stories and we need to learn to attend to the secret and cover stories that children live in school. Children's stories and stories of children also shape the negotiation of a curriculum of lives.

We attend to the nested milieus, in-classroom places, out-of-classroom places, out-of-school places, storied places filled with stories of teachers, teacher stories, stories of school, school stories, stories of families, and families' stories. We (Clandinin \& Connelly, 1995) described the out-of-classroom places as shaped by what is funneled onto the landscape via a metaphoric conduit. This funneled-in prescriptive knowledge is part of these nested milieus. Narrative understandings of diverse subject matters are also part of a negotiation of a curriculum of lives. (Clandinin \& Connelly, 1998)

Understanding curriculum in narrative terms highlights that, within this complex fluid mix, lives are what become central. Lives, people's experiences, that is, who each of us are, and who we are becoming, are central. Attending narratively highlights the importance of staying wakeful to the experience children and families are living both in and out of schools, to the dreams children hold for their lives, to the dreams families hold for their children's lives, to the gaps, silences and exclusions shaped in the bumping places of children and families' experiences in schools (Clandinin et al,2006). The negotiation of a curriculum of lives that continuously seeks to re-form, to re-make the silences, to hear and to learn from children's and teachers' stories about their experiences as they compose their lives in schools is complex, tension-filled, and challenging. When we also understand the ongoing negotiation of curriculum making as the ongoing negotiation of children's and teachers' stories to live by (Connelly \& Clandinin, 1999), that is, as the ongoing negotiation of identities, the negotiation of who each are of us are and are becoming, there is a place to begin to reimagine student engagement narratively. 


\section{Reimagining Student Engagement Narratively}

Understanding curriculum making as negotiating a curriculum of lives, including negotiating stories to live by, helps me wonder about thinking narratively about student engagement. Firstly, to understand student engagement we need to understand from within the context of ongoing stories to live by, a life in motion. Secondly, we need to come alongside each child in the midst of his/her storied life in order to understand the stories they are living and telling in that moment (Clandinin, 2007). Thirdly, we need to understand the narrative contexts shaped by stories of school, school stories, cultural stories, subject matter stories, teacher stories, stories of teachers and stories of the children who live in those landscapes. This complex interplay of stories - children's stories, stories of children, teachers' stories, stories of teachers, school stories, stories of school, families' stories, stories of families-are always moving, changing, shifting as one story calls forth an expression of someone's knowing that subsequently calls forth another's, and so on (Clandinin et al., 2006). From within this complex mix, perhaps we can begin to think about what student engagement would mean for each child, each teacher, in each moment.

In order to understand student engagement narratively, we need to understand the stories each child is living in a moment, trying to attend from within the three dimensional narrative inquiry space along temporal, social and place dimensions (Clandinin \& Connelly, 2000). As well we need to understand something of the classroom stories, the family stories and the social and cultural narratives in which each child is embedded. We do this in relational ways so that we might be attentive to the possibility that the stories I might imagine are being lived out by each child are not the stories that he/she would tell of that moment. Understandings of student engagement would emerge from within the complex milieu of stories.

Returning to the storied fragments, we are called to wonder what is happening in each moment for each child. In the first moment the story of citizenship education that is being composed and lived out around the book reading, calls each child to respond, to tell his/her stories. Attention was present both at the time of reading as well as when each child spoke. As one child's story called forth another story, we realized they were placing themselves within each other person's story, that is, they were engaging in a kind of world traveling (Lugones, 1987). In this way the story telling and story responding, created resonant remembrances (Hoffman, 1994) that reverberated through their own experiences. At first, with his head down, one child appeared unengaged. Yet our view of him as unengaged was belied when he began 
to tell his stories of resonant moments of tension. The teacher, reflecting back on this moment, noted that many other stories tumbled forth. What the book and each other's stories called forth from each child clearly mattered to them as they listened intently to each other. The teacher recalls sharing her story that she was once called "Japanese Girl." In the second storied fragment, however, there was also resonance as the teacher and the child engaged together in an interview of teacher questions raised by the textbook and mandated curriculum and the child's answers from her storied knowledge. There was also resonance as, by wordless, tacit understanding, structures were built as many students began to compose another curriculum.

In thinking about student engagement framed as a narrative concept, we are returned to considerations of the lives that are being composed and lived out in schools by teachers, children, parents, and others. Thinking narratively about student engagement puts lives at the centre of curriculum making and calls us to ask questions about our purposes, intentions and meaning making in these places called schools.

\section{Notes}

1. This research is supported by a Social Sciences and Humanities Research Council of Canada grant to D. Jean Clandinin, Janice Huber, M. Shaun Murphy and Anne Murray Orr.

\section{References}

Aoki, T. (1993). Legitimating lived curriculum: Towards a curricular landscape of multiplicity. Journal of Curriculum and Supervision, 8(3), 255-268.

Clandinin, D. J. (2007). Handbook of narrative inquiry: Mapping a methodology. Thousand Oaks, CA: Sage.

Clandinin, D. J., Huber, J., Huber, M., Murphy, M. S., Murray-Orr, A., Pearce, M., \& Steeves, P. (2006). Composing diverse identities: Narrative inquiries into the interwoven lives of children and teachers. London: Routledge.
Clandinin, D. J., \& Connelly, F. M. (2000). Narrative inquiry: Experience and story in qualitative research. San Francisco: Jossey-Bass.

Clandinin, D. J., \& Connelly, F.M. (1998). Stories to live by: Narrative understandings of school reform. Curriculum Inquiry, 28(2), 149-164.

Clandinin, D. J., \& Connelly, F.M. (1996). Teachers' professional knowledge landscapes: Teacher stories-stories of teachersschool stories-stories of school. Educational Researcher, 25(3), 24-30. 
Clandinin, D. J., \& Connelly, F.M. (1995). Teachers' professional knowledge landscapes. New York: Teachers College Press.

Clandinin, D. J., \& Connelly, F.M. (1992). The teacher as curriculum maker. In P. Jackson (Ed.), Handbook of research on curriculum (pp. 363-401). American Educational Research Association. New York: MacMillan Press.

Connelly, F. M., \& Clandinin, D. J. (1999). Shaping a professional identity: Stories of educational practice. New York: Teachers College Press.

Connelly, F.M., \& Clandinin, (1988). Teachers as curriculum planners: Narratives of experience. New York: Teachers College Press.

Hoffman, E. (1994). Let memory speak. The New York Times Book Review, January 23, 1994.
Lugones, M. (1987). Playfulness, "world"-travelling, and loving perception. Hypatia, 2(2), 3-37.

Lyons, N. (1990). Dilemmas of knowing: Ethical and epistemological dimensions of teacher's work and development. Harvard Educational Review, 60(2), 159-180.

Murphy, M.S. (2004). Understanding children's knowledge: A narrative inquiry into school experiences. Unpublished doctoral dissertation, Edmonton, University of Alberta.

Portelli, J., \& Vibert, A. (2001). Beyond common educational standards: Toward a curriculum of life. In J. Portelli \& R. P. Solomon (Eds.), The Erosion of democracy in education (pp. 6-82). Calgary: Detselig.

Say, A. (1999). Tea with milk. Boston, MA: Walter Lorraine Books.

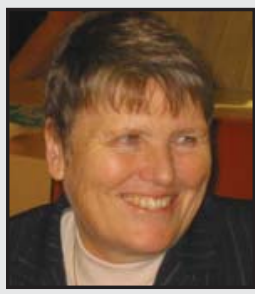

D. Jean Clandinin is Professor and Director of the Centre for Research for Teacher Education and Development at the University of Alberta. She is a former teacher, counselor, and psychologist. She is co-author with Michael Connelly of four books and many chapters and articles. Her most recent coauthored book, Composing Diverse Identities: Narrative Inquiries into the Interwoven Lives of Children and Teachers, drew on research with children and teachers in urban schools. She is the editor of the Handbook of Narrative Inquiry: Mapping a methodology. A past Vice President of Division B of AERA and the 1993 winner of AERA's Early Career Award, she is also the 1999 winner of the Canadian Education Association Whitworth Award for educational research; the 2002 winner of AERA's Division B Lifetime Achievement Award; the 2001 winner of the University of Alberta Kaplan Research Achievement Award; and a 2004 Killam Scholar.

LINK TO:

http://www.uofaweb.ualberta.ca/elementaryed/CRTED.cfm 